\title{
Purchase Decisions of Muslim Clothing Influenced by Halal Lifestyle, Product Quality, Price with Religiosity as Moderation
}

\author{
Laila Rahmawati ${ }^{1}$, and Endah Nur Fitriyani ${ }^{1 *}$ \\ ${ }^{1}$ Faculty of Islamic Economics and Business, IAIN Salatiga, Indonesia
}

\begin{abstract}
This study aims to analyze the factors that influence the decision to purchase muslim clothing. This research uses quantitative research with primary data. Data collection techniques by distributing questionnaires either directly or via google form. The data obtained were then analyzed using SPSS tools. The sample in this study amounted to 90 respondents who are active members of Zoya Salatiga. The results showed that the halal lifestyle and price variables had a positive and significant effect on purchasing decisions, while the product quality variable had a positive and insignificant effect on purchasing decisions. Religiosity can moderate the variables of halal lifestyle, product quality, and price on purchasing decisions.
\end{abstract}

Keywords: purchasing decisions, halal lifestyle, product quality, price, religiosity

\section{Introduction}

The growth of fashion products in Indonesia shows an increase from every year, data from BPS shows that one of the main contributors to the creative economy's GDP is fashion with a contribution of $18.01 \%$ equivalent to Rp. 166 trillion in 2016. In the same year the fashion sub-sector contributed $56 \%$ of the total creative economy exports. Exports of fashion products have increased in the last three years. This is a potential for companies that want to market their products for the fashion industry, especially muslim clothing. The fashion industry is greatly influenced by changes in style, including lifestyle.

Lifestyle also affects the whole person in interacting with his environment. Halal lifestyle which is becoming a trend becomes interesting to study because currently halal lifestyle is developing all over the world. Halal lifestyle can be interpreted as a person's lifestyle which is carried out based on Islamic thoughts and concepts by paying attention to what is allowed and prohibited by religion such as carrying out its orders and staying away from its prohibitions, implementing a sharia lifestyle, covering the genitals, and others.

Halal lifestyle found in Indonesia is not only in terms of halal food and drinks, but also in terms of halal clothing, halal finance, halal tourism, halal cosmetics and so on. Someone

* Corresponding author: endahfitriyani@iainsalatiga.ac.id 


\section{$A \overline{I E B} \quad$ Annual International Conference \\ on Islamic Economics and Business, 2021}

chooses a product with the influence of several different factors, in general the factors that influence it are in terms of the price of a product, the quality of the product, the lifestyle of each individual, current trends and how to get the product which is often a consideration (Ismailia, 2018). Therefore, every individual, especially Muslim women, when choosing clothes will be more selective, although sometimes there are things that become benchmarks in purchasing goods or services, one of which is the quality of products that comply with sharia provisions.

One of the factors that influence consumers in making product purchasing decisions is because of the quality contained in the product. Product quality is a product or service characteristic that is able to satisfy consumer needs that can be stated or implied. A product usually has two types of benefits, namely functional benefits and psychological benefits (Ferhat \& Hidayatullah, 2019). Apart from product quality, a consumer chooses an item based on price. Price is an important component when someone decides to buy an item, often the price is used as an indicator of value when the price is associated with the perceived benefits for an item or service. Price is the value exchanged by consumers for the benefits of consuming, using and owning a product or service. When the price matches the quality of the goods offered, consumers will decide to buy the product (Pratiwi, 2021).

Consumer decision making means that consumers have the ability to obtain and analyze information about the product which is manifested in the form of an attitude to choose or buy goods based on existing choices (Khuwaroh et al., 2018). According to Kotler (2008), purchasing decisions are actions to want to buy or not to a product. In deciding to buy, usually a consumer goes through several stages including problem recognition, information search, alternative evaluation, decision to buy or not and post-purchase behavior (Nador, 2017). The attitude of religiosity is still rarely found in Muslim consumers when spending their money especially in terms of clothing. Many of the Muslims who buy clothes just to satisfy their desires and follow trends, many are still tempted by attractive offers and affordable prices and decide to buy a product without distinguishing between needs and wants.

\section{Literature Review}

\subsection{Halal Lifestyle}

Lifestyle can be interpreted as a personal reflection of a person who interacts with the environment. While halal is a word that comes from Arabic which means permitted or in accordance with the law. The word halal is also interpreted as something that if used does not result in getting sin (torment). Halal is something that is allowed to be consumed or used according to the shari'a, so halal does not only concern aspects of halal food and drinks, but also everything related to one's life. In Islamic teachings, a Muslim in consuming products must be guaranteed halal and pure (Adinugraha \& Sartika, 2019). Halal lifestyle is a person's lifestyle which is manifested in halal activities and activities, his interests and opinions in spending his money for daily consumption and other pleasures in a lawful manner and how to allocate time in a lawful manner as well (Ismailia, 2018). Halal lifestyle can be seen from various factors that are determined from consumption behavior that has been carried out in daily life. Halal lifestyle indicators include how to spend wealth, how to do activities in daily life and how to spend the time they have.

\subsection{Product Quality}

Quality is an important thing that must be considered by a company if it wants to have a product that can compete in the market and can meet consumer needs. According to Kotler 


\section{$A \overline{I E B} \quad$ Annual International Conference \\ on Islamic Economics and Business, 2021}

(2008), product quality is the overall characteristics and properties of a product that affect its ability to satisfy needs. Product quality is the overall combination of characteristics of goods and services from marketing, engineering, manufacture and maintenance that makes products and services meet consumer expectations (Alim et al., 2018). High product quality will be able to meet the psychological and physical needs of consumers to the fullest. According to Tjiptono et al., (2008) describes eight indicators that can be used to analyze product quality characteristics, including: performance, features, reliability, conformance, durability, service ability, aesthetics, precieved quality.

\subsection{Price}

Currently, price is still an important element that influences someone in making a purchase because price is one of the four marketing mixes or marketing mix, namely the 4Ps (product, price, distribution and promotion). Price can also determine market share and profits in a company (Arinda, 2020). Kotler (2008) defines price as the amount of money charged for a product or service, or the amount of value that customers exchange for the benefits of using the product or service. Price is also interpreted as a consumer's willingness to pay an amount of money according to purchasing power, adjusted for quality, and using other similar products as a comparison with the purchased product (Setiyawan, 2019). To make a profit, a company must be able to cover all the costs of producing services and marketing then adding a margin to make a profit. According to Kotler (2008) there are several price indicators including price affordability, product quality compliance, price competitiveness, price suitability and benefits.

\subsection{Purchase Decision}

One of the main components of consumer behavior is the purchase decision. Purchasing decisions are the stages that consumers take when buying goods and services. Purchasing decisions are a problem-solving approach to the process of purchasing goods and services to meet human wants and needs (Martini, 2015). The purchase decision is the consumer's final decision in buying a product which is formed from a series of stages of pre-purchase behavior activity. Decision making as an important process that influences consumer behavior is very important for marketers to understand. Decision making can be viewed as a system consisting of inputs, processes and outputs (Reven et al., 2017). According to (Nasution, 2018), there are several stages of the decision-making process, including: problem recognition, information search, alternative evaluation, purchase decisions and post-purchase behavior. In making purchasing decisions, there are several indicators including (Nasution, 2018): product choice, brand choice, seller choice, time of purchase.

\subsection{Religiosity}

Religious activities are not only in terms of worship, consumption activities must also be based on religion to consider whether or not the consumer behavior carried out by Lubis (2018). Individuals with a high level of religious belief will tend to use religion as the basis for individual decision making. According to Glock \& Stark in Nur \& Ridla (2015) the measurement of religiosity can use the following indicators:

1. Belief or ideology, namely the extent to which a person believes in dogmatic things in the teachings of his religion. Such as beliefs about God, angels, heaven and hell, as well as God's laws on human behavior. 


\section{$A \mathrm{IC} \overline{I F B}$ Annual International Conference \\ on Islamic Economics and Business, 2021}

2. Religious or ritualistic practices, are certain activities in religion that are required and recommended to be carried out by adherents. For example prayer, zakat, fasting and so on.

3. Religious or intellectual knowledge, namely how far a person knows and understands about religious teachings and their holy books. In Islam, this intellectual aspect contains the content of the Qur'an and the basics of religion that must be believed and implemented by its followers.

4. Experience or experiential, is a religious experience in the form of feelings or emotions that have been experienced and felt. Like feeling close to God, feeling afraid of committing sins and so on.

5. Practices or consequences, are worldly consequences of beliefs, actions, experiences and individual religious knowledge, including what must be done and how the attitude must be held by individuals as a consequence of their religion.

\subsection{Hypothesis of the Research}

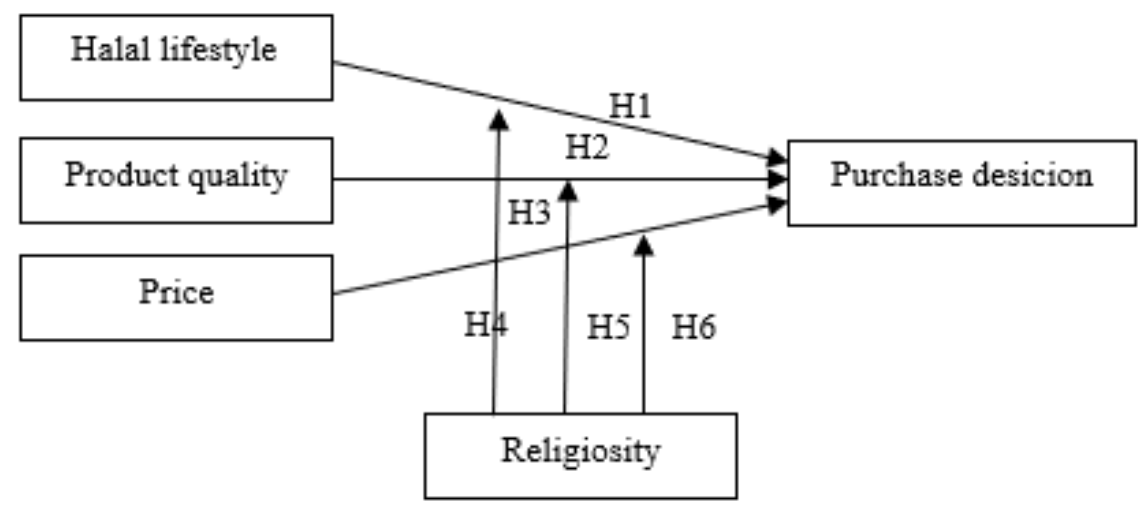

Fig. 1. Research framework

Hypothesis of this study is as follows:

H1 : Halal Lifestyle has a positive and significant effect on purchasing decisions.

$\mathrm{H} 2$ : Product quality has a positive and significant effect on purchasing decisions

H3 : Price has a positive and significant effect on purchasing decisions.

H4 : Religiosity strengthens the influence of halal lifestyle on purchasing decisions

H5 : Religiosity strengthens the influence of product quality on purchasing decisions

H6 : Religiosity strengthens the effect of price on purchasing decisions.

\section{Method}

Type of research is quantitative research. The source of the data used in this study is primary data obtained from a questionnaire addressed to the Zoya Hijab Gallery consumers, Salatiga. As for testing the moderating variable, it is done using the MRA (Moderated Regression Analysis) test. In this study, sampling was carried out using probability sampling technique. Calculation of the number of samples is carried out using the Slovin formula with a population of 904 consumers so that a sample of 90 respondents is obtained. 


\section{Result and Discussion}

\subsection{Result}

\subsubsection{Validity Test}

Validity test is used to analyze the validity of a questionnaire. It is stated that the item is valid if the correlation value is starred with two possibilities, namely one star correlation with the Sig value. 0.05 and two stars with a value of Sig. 0.01 (Bawono, 2006).

Table 1. Validity Test

\begin{tabular}{|c|c|c|c|}
\hline Variabel & Item & Pearson Correlation & Result \\
\hline \multirow{3}{*}{ Halal Lifestyle $\left(\mathrm{X}_{1}\right)$} & Item 1 &, $819^{* * *}$ & Valid \\
\hline & Item 2 &, $761^{* *}$ & Valid \\
\hline & Item 3 &, $806^{* *}$ & Valid \\
\hline \multirow{8}{*}{ Product Quality $\left(\mathrm{X}_{2}\right)$} & Item 1 &, $673^{* *}$ & Valid \\
\hline & Item 2 &, $880^{* * *}$ & Valid \\
\hline & Item 3 & $676^{* * *}$ & Valid \\
\hline & Item 4 &, $877^{* *}$ & Valid \\
\hline & Item 5 & $671^{* *}$ & Valid \\
\hline & Item 6 &, $785^{* *}$ & Valid \\
\hline & Item 7 &, $802^{* * *}$ & Valid \\
\hline & Item 8 &, $789^{* *}$ & Valid \\
\hline \multirow{4}{*}{ Price $\left(\mathrm{X}_{3}\right)$} & Item 1 &, $847^{* *}$ & Valid \\
\hline & Item 2 & ,929** & Valid \\
\hline & Item 3 &, $789^{* * *}$ & Valid \\
\hline & Item 4 &, $889^{* *}$ & Valid \\
\hline \multirow{4}{*}{ Purchase Decision (Y) } & Item 1 &, $779^{* *}$ & Valid \\
\hline & Item 2 & $837^{* *}$ & Valid \\
\hline & Item 3 &, $877^{* *}$ & Valid \\
\hline & Item 4 & ,905** & Valid \\
\hline \multirow{5}{*}{ Religiosity (Z) } & Item 1 & $604^{* *}$ & Valid \\
\hline & Item 2 &, $867^{* *}$ & Valid \\
\hline & Item 3 &, $866^{* *}$ & Valid \\
\hline & Item 4 &, $827^{* *}$ & Valid \\
\hline & Item 5 & $673^{* *}$ & Valid \\
\hline
\end{tabular}

Source: Primary Data Processed, 2021

The results of the validity test can be seen if all the question items in the questionnaire have a two star correlation with the Sig value. 0.01 so that all of the question items can be used. 


\section{$A I \overline{I E B}$ Annual International Conference \\ on Islamic Economics and Business, 2021}

\subsubsection{Reliability Test}

Measurement of the reliability test can be carried out using the Croanbach alpha statistical test provided that the variable is said to be reliable if the Croanbach alpha value is $>0.60$ (Ruhamak \& Syai'dah, 2018).

Table 2. Reliability Test

\begin{tabular}{|l|c|c|}
\hline \multicolumn{1}{|c|}{ Variabel } & Cronbach's Alpha & Result \\
\hline Halal Lifestyle $\left(X_{1}\right)$ & 0,820 & Reliable \\
\hline Product quality $\left(\mathrm{X}_{2}\right)$ & 0,784 & Reliable \\
\hline Price $\left(\mathrm{X}_{3}\right)$ & 0,833 & Reliable \\
\hline Purchase decision $(\mathrm{Y})$ & 0,828 & Reliable \\
\hline Religiosity $(\mathrm{Z})$ & 0,798 & Reliable \\
\hline
\end{tabular}

Source: Primary Data Processed, 2021

The results of the reliability test can be seen that the value of Croanbach's alpha on all items is more than 0.60 so it can be said to be reliable.

\subsubsection{Normality Test}

The normality test is used to test the data of the independent variable and the dependent variable whether it is normally or not normally distributed. This test can use the significance value in the Kolmogorov-Smirnov column. The results of the normality test are normally distributed if the significance value (2-tailed) 0.05 (Sunyoto, 2013).

Table 3. Normality Test

\begin{tabular}{|c|c|c|c|}
\hline Test & Sig. & Asymp. Sig. (2 Tailed) & Result \\
\hline Kolmogorov-Smirnov & 0,05 &, $054^{\mathrm{c}}$ & Normal \\
\hline
\end{tabular}

Source: Primary Data Processed, 2021

The results of the normality test can be seen that the Asymp value. Sig. (2-tailed) of 0.054 $>0.05$, it can be concluded that the data is normally distributed.

\subsubsection{Multicollinearity Test}

The regression model is said to be good if there is no correlation between the independent variables. If the value of tolerance $(\alpha)$ count $>0.05$ or VIF count $<10$, then the independent variable does not experience multicollinearity.

Table 4. Multicollinearity test

\begin{tabular}{|l|c|c|c|}
\hline \multicolumn{1}{|c|}{ Variable } & Tolerance & VIF & Result \\
\hline Halal Lifestyle $\left(X_{1}\right)$ & 0,978 & 1,023 & No Multicollinearity \\
\hline Product quality $\left(\mathrm{X}_{2}\right)$ & 0,963 & 1,038 & No Multicollinearity \\
\hline Price $\left(\mathrm{X}_{3}\right)$ & 0,887 & 1,127 & No Multicollinearity \\
\hline
\end{tabular}

Source: Primary Data Processed, 2021 


\section{$A I C \overline{I E B} \quad$ Annual International Conference \\ on Islamic Economics and Business, 2021}

The results of the multicollinearity test can be seen if each variable has a tolerance value $>0.10$ with a VIF value $<10.00$ so it does not indicate that multicollinearity occurs.

\subsubsection{Heteroscedasticity Test}

To determine the presence or absence of heteroscedasticity, it can be seen from the significance value of the Glejser test with the condition that if the value of Sig. > 0.05, then there is no heteroscedasticity and vice versa. The following are the results of heteroscedasticity testing.

Table 5. Heteroscedasticity Test Result

\begin{tabular}{|l|c|c|}
\hline \multicolumn{1}{|c|}{ Variable } & Sig. & Result \\
\hline Halal Lifestyle $\left(X_{1}\right)$ & 0,302 & No Heteroscedasticity \\
\hline Product quality $\left(\mathrm{X}_{2}\right)$ & 0,264 & No Heteroscedasticity \\
\hline Price $\left(\mathrm{X}_{3}\right)$ & 0,500 & No Heteroscedasticity \\
\hline
\end{tabular}

Source: Primary Data Processed, 2021

The results of the heteroscedasticity test can be seen if all variables (X) have a significance value $>0.05$ so there is no heteroscedasticity.

\subsubsection{Multiple Regression Test}

In this study, the multiple regression analysis test aims to determine how much influence the halal lifestyle (X1), product quality (X2), and price (X3) have on the buying decision of Zoya Salatiga Muslim clothing (Y). Multiple regression test can be searched using the formula in the following equation:

$$
y=\beta_{0}+\beta_{1} x_{1}+\beta_{2} X_{2}+\beta_{3} X_{3}+e
$$

Table 6. Multiple Regression Test

\begin{tabular}{|l|c|}
\hline \multicolumn{1}{|c|}{ Model } & B \\
\hline (Constant) & 6,198 \\
\hline Halal Lifestyle & 0,410 \\
\hline Product quality & 0,196 \\
\hline Price & 0,197 \\
\hline
\end{tabular}

Source: Primary Data Processed, 2021

According to table 4.1.6 above the results of the multiple regression produce the following equation:

$$
y=6,198+0,410 X_{1}+0,196 X_{2}+0,197 X_{3}+e
$$

1) The constant of 6.198 indicates that if the variables of halal lifestyle (X1), product quality (X2), price (X3) are fixed or unchanged or 0, then the decision to purchase Zoya Salatiga Muslim clothing is at 6.198 .

2) The regression coefficient for halal lifestyle (X1) is 0.410 , indicating that if the halal lifestyle variable (X1) increases by $1 \%$, the purchase decision will increase by 0.410 . It 


\section{$A I C \overline{I E B}$ Annual International Conference \\ on Islamic Economics and Business, 2021}

can be concluded that the halal lifestyle variable influences the purchasing decision of Zoya Salatiga's Muslim clothing.

3) Product quality regression coefficient (X2) of 0.196 indicates that if the product quality variable (X2) increases by $1 \%$, the purchasing decision will increase by 0.196 . It can be concluded that the product quality variable influences the purchasing decision of Zoya Salatiga Muslim clothing.

4) The price regression coefficient (X3) of 0.197 indicates that if the price variable (X3) increases by $1 \%$, the purchasing decision will increase by 0.197 . It can be concluded that the price variable has an effect on purchasing decisions for Zoya Salatiga Muslim clothing.

\subsubsection{T Test}

The basis of the $\mathrm{T}$ test is that the independent variable $(\mathrm{X})$ is said to have an effect on the dependent variable $(\mathrm{Y})$ if it has a Sig value. $<0.05$ and vice versa. The following are the results of the $\mathrm{T}$ test that has been carried out.

Table 7. T Test

\begin{tabular}{|l|c|c|c|}
\hline \multicolumn{1}{|c|}{ Variable } & Sig & t table & t count \\
\hline Halal Lifestyle $\left(\mathrm{X}_{1}\right)$ & 0,011 & 1,662 & 2,587 \\
\hline Product quality $\left(\mathrm{X}_{2}\right)$ & 0,085 & 1,662 & 1,744 \\
\hline Price $\left(\mathrm{X}_{3}\right)$ & 0,032 & 1,662 & 2,177 \\
\hline
\end{tabular}

Source: Primary Data Processed, 2021

\subsubsection{F Test}

The basis for taking the provisions on the F test is if the value of Sig. $<0.05$, then the conclusion is $\mathrm{H} 0$ is rejected and $\mathrm{H} 1$ is accepted and vice versa. Here are the results of the F test regression test.

Table 8. F Test

\begin{tabular}{|l|c|c|c|}
\hline \multicolumn{1}{|c|}{ Variabel } & Sig. & f Count & f Table \\
\hline Halal Lifestyle $\left(\mathrm{X}_{1}\right)$ & 0,010 & 5,609 & 2,48 \\
\hline Product quality $\left(\mathrm{X}_{2}\right)$ & 0,010 & 5,609 & 2,48 \\
\hline Price $\left(\mathrm{X}_{3}\right)$ & 0,010 & 5,609 & 2,48 \\
\hline
\end{tabular}

Source: Primary Data Processed, 2021

The results of the regression test in table 4.12 obtained the value of Sig. a number of 0.010 so that $\mathrm{H} 0$ is rejected and $\mathrm{H} 1$ is accepted, and the calculated $\mathrm{F}$ value is 5.609 > F table 2.48, so $\mathrm{H} 1$ is accepted. It can be concluded that the variables of halal lifestyle (X1), product quality (X2) and price (X3) simultaneously have a positive and significant influence on the purchasing decision variable $(\mathrm{Y})$.

\subsubsection{Coefficient of Determination Test $\left(\mathrm{R}^{2}\right)$}

The $\mathrm{R}^{2}$ test was conducted to measure the percentage effect of all independent variables on the dependent variable. This test can be known through the value of the coefficient of 


\section{$A I C \overline{I E B} \quad$ Annual International Conference \\ on Islamic Economics and Business, 2021}

determination provided that if the coefficient value is low then the ability of the independent variable $(\mathrm{X})$ to explain the dependent variable $(\mathrm{Y})$ is limited. However, if the coefficient of determination is close to 1 , then the independent variable $(\mathrm{X})$ provides all the information to predict the dependent variable (Y) (Ghozali, 2013). Here are the results of the Coefficient of Determination Test $\left(\mathrm{R}^{2}\right)$.

Table 9. Coefficient of Determination Test

Model Summary

\begin{tabular}{|l|l|l|l|l|}
\hline Model Summary & R & R Square & Adjustes R Square & $\begin{array}{l}\text { Std. Error of the } \\
\text { Estimate }\end{array}$ \\
\hline 1 &, $429^{\mathrm{a}}$ & 0,184 & 0,145 & 2,827 \\
\hline
\end{tabular}

Predictors: (Constant), Religiosity, Halal Lifestyle, Product Quality, Price

Dependent Variable: Purchase Decision

\subsubsection{Moderated Regression Analysis (MRA)}

This MRA test was conducted to determine whether the moderating variable (religiosity) could strengthen or weaken the various independent variables (halal lifestyle, product quality and price) on the dependent variable (purchase decision). The following are the results of the MRA test.

1. Religiosity moderates the effect of halal lifestyle on purchase decisions

Table 10. MRA 1

\begin{tabular}{|l|c|c|}
\hline \multicolumn{1}{|c|}{ Output } & R Square & \% \\
\hline Simple Regression (X1 to Y) & 0,72 & 7,2 \\
\hline Multiple Regression (X1 to Y to Z) & 0,154 & 15,4 \\
\hline
\end{tabular}

Source: Primary Data Processed, 2021

The value of $\mathrm{R}^{2}$ in the first regression was 0.72 or $7.2 \%$, while after the multiple regression equation the value of $\mathrm{R}^{2}$ increased to 0.154 or $15.4 \%$. So it can be concluded that the religiosity variable $(\mathrm{Z})$ is able to moderate (strengthen) the effect of the halal lifestyle variable (X1) on purchasing decisions (Y).

2. Religiosity moderates the effect of product quality on purchasing decisions

Table 11. MRA 2

\begin{tabular}{|l|c|c|}
\hline \multicolumn{1}{|c|}{ Output } & R Square & \% \\
\hline Simple Regression (X2 to Y) & 0,037 & 3,7 \\
\hline Multiple Regression (X2 to Y to Z) & 0,082 & 8,2 \\
\hline
\end{tabular}

Source: Primary Data Processed, 2021

The value of $\mathrm{R}^{2}$ is 0.037 or $3.7 \%$, while after there is a multiple regression equation, the value of $\mathrm{R}^{2}$ increases to 0.082 or $8.2 \%$. By reviewing these results, it can be interpreted that $\mathrm{H} 5$ is accepted. So that it can be seen that the religiosity variable $(\mathrm{Z})$ is able to moderate (strengthen) the effect of the product quality variable (X2) on purchasing decisions (Y).

3. Religiosity moderates price on purchase decisions 
Table 12. MRA 3

\begin{tabular}{|l|c|c|}
\hline \multicolumn{1}{|c|}{ Output } & R Square & \% \\
\hline Simple Regression (X3 to Y) & 0,077 & 7,7 \\
\hline Multiple Regression (X3 to Y to Z) & 0,107 & 10,7 \\
\hline
\end{tabular}

Source: Primary Data Processed, 2021

The value of $\mathrm{R}^{2}$ in the simple regression test is $7.7 \%$, after obtaining the multiple regression equation, the value of $\mathrm{R}^{2}$ increases to $10.7 \%$. With these acquisitions, it can be concluded that $\mathrm{H6}$ is accepted. So that it can be seen that the religiosity variable $(\mathrm{Z})$ is able to moderate (strengthen) the effect of the price variable (X3) on purchasing decisions (Y).

\subsection{Discussion}

In accordance with the purpose of this study, namely to determine the effect of halal lifestyle, product quality and price on purchasing decisions with religiosity as a moderating variable, the following issues will be discussed:

\section{The Effect of Halal Lifestyle on Purchase Decisions}

From the results of the Partial T test, the value of Sig. the halal lifestyle variable (X1) is 0.011 $<0.05$, and the t-count value is $2.587>$ the $\mathrm{t}$-table value is 1.662 . Thus $\mathrm{H} 1$ is accepted and $\mathrm{HO}$ is rejected, it can be stated that halal lifestyle (X1) can have a positive and significant effect on purchasing decisions (Y). This is supported by research from Hoiriyah \& Chrismardani (2021) which says that halal lifestyle has a positive and significant effect on purchasing decisions. However, this is not in accordance with the results of research from Mongisidi et al. (2019), the study found that lifestyle did not have a positive and significant effect on purchasing decisions.

\section{The Effect of Product Quality on Purchase Decisions}

According to the results of the partial $t$ test, the product quality variable has a significance value of $0.085>0.05$, and the t-count value is $1.744>$ the $t$-table value is 1.662 . Thus $\mathrm{H} 2$ is rejected and $\mathrm{H} 0$ is accepted, it can be concluded that the product quality variable (X2) has a positive and insignificant effect on purchasing decisions (Y). The results of this study are in accordance with research conducted by Farisi (2018) which states that product quality has a positive and insignificant effect on purchasing decisions. However, this study does not support the research conducted by Agung et al. (2020), Kurnianingsih \& Sugiyanto (2019), Putra (2017) and Habibah (2016), these studies show that product quality has a positive and significant influence on purchasing decisions.

\section{The Influence of Price on Purchase Decisions}

From the Partial T-test that has been carried out, it produces a significant value of the price variable of $0.032<0.05$, and the t-count value is $2.177>$ the t-table value is 1.662 . With these results, a decision can be made that $\mathrm{H} 3$ is accepted and $\mathrm{H} 0$ is rejected, so it can be seen that the price variable (X3) has a positive and significant effect on purchasing decisions (Y). These results support research from Pratiwi (2021), Hariyanto et al. (2021), Mapaung et al. (2021), and Alfarizi (2021) who found the results that price had a positive and significant effect on purchasing decisions. However, these results are not in line with the results of research from Nasution (2018) which says that price does not have a positive and significant effect on purchasing decisions. 


\section{$A \mathrm{IC} \quad$ Annual International Conference \\ on Islamic Economics and Business, 2021}

4. Religiosity moderates the effect of Halal Lifestyle on Purchase Decisions

According to the explanation in table 10 above, the $\mathrm{R}^{2}$ value in the first simple regression is 0.72 or $7.2 \%$, while after the second multiple regression equation the $\mathrm{R}^{2}$ value increases to 0.154 or $15.4 \%$. By reviewing these acquisitions, it can be interpreted that $\mathrm{H} 4$ is accepted and $\mathrm{HO}$ is rejected, it can be seen that the religiosity variable $(\mathrm{Z})$ is able to moderate (strengthen) the influence of halal lifestyle (X1) on purchasing decisions (Y). The results of this study are not in accordance with the research conducted by Sari \& Widodasih (2021) which stated that religiosity as a moderating variable did not strengthen the influence of lifestyle on purchasing decisions.

5. Religiosity moderates the effect of product quality on purchasing decisions

From the description of table 11 , the results obtained in a simple regression with an $\mathrm{R}^{2}$ value of 0.037 or $3.7 \%$, after the multiple regression equation the R2 value increased to 0.082 or $8.2 \%$. With these results, it can be seen that $\mathrm{H} 5$ is accepted and $\mathrm{H} 0$ is rejected. So it can be concluded that the religiosity variable $(\mathrm{Z})$ can moderate (strengthen) the effect of product quality (X2) on purchasing decisions (Y). This is reinforced by the results of research from Shadiq (2020) which states that religiosity is able to strengthen the influence of product quality on consumer buying decisions.

6. Religiosity moderates the effect of price on purchasing decisions

According to the explanation in table 12 it can be seen that the value of $\mathrm{R}^{2}$ in the simple regression is 0.077 or $7.7 \%$, while after the multiple regression equation the $\mathrm{R}^{2}$ value increases to 0.107 or $10.7 \%$. By reviewing the acquisition, it means that $\mathrm{H} 6$ is accepted and $\mathrm{HO}$ is rejected. So it can be seen that the religiosity variable ( $\mathrm{Z})$ is able to moderate (strengthen) the influence between price (X3) and purchasing decisions (Y). This is supported by research conducted by Nurwahyudi \& Haryanto (2018), which explains in their research that the level of religiosity will affect the decision to choose an item based on cost or price, so religiosity is able to moderate the relationship between price and purchasing decisions.

\section{Conclusion}

The results of this study indicate that halal lifestyle and price affect purchasing decisions, while the product quality variable shows no significant positive results on purchasing decisions so that product quality does not affect purchasing decisions. Religiosity as a moderating variable can strengthen the influence of halal lifestyle, product quality, and price on purchasing decisions.

\section{References}

Adinugraha \& Sartika. (2019). Halal Lifestyle di Indonesia. An-Nisbah: Jurnal Ekonomi Syariah Volume 05 (02), 57-81.

Agung, M., Rachma, N., \& Hufron, M. (2020). Analisis Pengaruh Desain Produk, Kualitas Produk, Harga Kompetitif Dan Citra Merek Terhadap Keputusan Pembelian (Studi Kasus Pada Konsumen Distro N19ab Karangploso Malang). Prodi Manajemen, 12 25.

Alfarizi, D. C. (2021). Pengaruh Harga, Promosi, Dan Kualitas Pelayanan Terhadap Keputusan Pembelian Pada Pengguna Aplikasi Kai Acces (Akses Kereta Api Indonesia). Jurnal Ilmu Dan Riset Manajemen, e-ISSN : 2461-0593.

Alim, S. A., Mawardi, M. K., \& Bafadhal, A. S. (2018). Pengaruh Persepsi Label Halal dan Kualitas Produk Terhadap Keputusan Pembelian Produk Fesyen Muslim ( Survei pada 


\section{$A \overline{I C B}$ Annual International Conference \\ on Islamic Economics and Business, 2021}

Pelanggan Produk Zoya Muslim di Kota Malang ). Jurnal Administrasi Bisnis, 62(1), 127-134.

Arinda, M. K. (2020). Pengaruh Halal Lifestyle, Harga, Dan Promosi Terhadapkeputusan Konsumenmemilih Kayla Nissasalon \& Spamuslimah. Journal of Chemical Information and Modeling, 105.

Bawono, A. (2006). Multivariate Analysis dengan SPSS. STAIN Salatiga Press.

Farisi, S. (2018). Pengaruh citra merek dan kualitas produk terhadap keputusan pembelian sepatu Adidas pada mahasiswa Universitas Muhammadiyah Sumatera Utara.

Ferhat, K., \& Hidayatullah, D. (2019). Pengaruh Perilaku Konsumen, Kualitas Produk, dan Harga produk terhadap Keputusan Pembelian Produk Busana Klamby. E-Proceeding of Management, 6(2), 18-44.

Ghozali. (2013). Aplikasi Analisis Multivariate dengan Program IBM SPSS 23. Universitas Diponegoro.

Habibah, U. (2016). Pengaruh Kualitas Produk Dan Harga Terhadap Keputusan Pembelian Produk Kosmetik Wardah Di Kota Bangkalan Madura. 1(1), 31-48.

Hariyanto, M., Herliani, F., \& Hasanah, M. (2021). Pengaruh Harga dan Kualitas Pelayanan Terhadap Keputusan Pembelian pada Minimarket Nahda Sungai Bengkal. Jurnal Hukum Islam, 4(1), 107-126.

Hoiriyah, Y. U., \& Chrismardani, Y. (2021). Pengaruh Gaya Hidup Halal, Label Halal Dan Harga Terhadap Keputusan Pembelian Pembelian Ms Glow (Studi Pada Mahasiswi Universitas Trunojoyo Madura). Jurnal Kajian Ilmu Manajemen, 1(2), 115-120.

Ismailia, Y. (2018). Pengaruh gaya hidup syariah dan harga terhadap keputusan pembelian pada klinik kecantikan muslimah aishaderm. Ekonomi Dan Bisnis Islam, 107.

Khuwaroh, K., Widarko, A., \& Anwaruddin, M. K. (2018). Analisis Pengaruh Label Halal, Keamanan Bahan, Promosi, Dan Harga Pada Produk Kosmetik Sariayu Terhadap Keputusan Pembelian Konsumen. Jurnal Professional FIS UNIVED, 5(1), $26-31$.

Kotler, P. (2008). Manajemen Pemasaran (Edisi 12 J). Indeks.

Kurnianingsih, W., \& Sugiyanto. (2019). Pengaruh Kualitas Produk Dan Promosi Penjualan Terhadap Keputusan Pembelian Pada Pt. Nestle Indonesia. Skripsi Respositari, 1(1), $510-524$.

Lubis, S. (2018). Pengaruh Religiusitas Dan Lokasi Terhadap Keputusan Pembelian Konsumen Pada Rahmat Syariah Swalayan City Walk Padangsidimpuan.

Mapaung, F. K., Arnold, M. W., Sofira, A., \& Aloyna, S. (2021). Pengaruh Harga, Promosi, Dan Kualitas Produk Terhadap Keputusan Pembelian Konsumen Indomie Pada Pt. Alamjaya Wirasentosa Kabanjahe. Jurnal Manajemen, 7(1), 49-64.

Martini, T. (2015). Analisis Pengaruh Harga, Kualitas Produk Dan Desain Terhadap Keputusan Pembelian Kendaraan Bermotor Merek Honda Jenis Skutermatic. Jurnal Penelitian, 9(1), 113-132.

Mongisidi, S. J., Sepang, J., \& Soepeno, D. (2019). Pengaruh Lifestyle Dan Harga Terhadap Keputusan Pembelian Sepatu Nike (Studi Kasus Manado Town Square). Jurnal EMBA: Jurnal Riset Ekonomi, Manajemen, Bisnis Dan Akuntansi, 7(3).

Nador, N. (2017). Pengaruh Kualitas Produk, Harga Produk dan Keamanan Produk Terhadap Keputusan Pembelian (Studi Pada Pasar Tradisional Madyopuro Kota Malang). EJurnal Riset Manajemen Prodi Manajemen Fakultas Ekonomi Unisma, 68-70.

Nasution, H. F. (2018). Pengaruh Kemudahan Dan Harga Terhadap Keputusan Pembelian Produk Pakaian Secara Online (Studi Kasus Mahasiswa Belanja Online Pada FEBI IAIN Padangsidimpuan). At-Tijaroh: Jurnal Ilmu Manajemen Dan Bisnis Islam, 4(1),

Nur, H., \& Ridla, M. R. (2015). Pengaruh Kualitas Pelayanan, Citra Lembaga Dan Religiusitas Terhadap Minat Muzakki Untuk Menyalurkan Zakat Profesi ( Studi di Pos Keadilan Peduli Ummat Yogyakarta ). Jurnal MD Membangun Profesionalisme Keilmuan, 207-228. 


\section{$A \mathrm{I} \overline{I E B}$ Annual International Conference \\ on Islamic Economics and Business, 2021}

Nurwahyudi, A., \& Haryanto, B. (2018). Peran Relegiusitas Dalam Memoderasi Keputusan Individu Dalam Memilih Sekolah Dasar Islam Terpadu Di Karanganyar. Capital: Jurnal Ekonomi Dan Manajemen, 1(2), 71.

Pratiwi, A. (2021). Pengaruh Harga terhadap Keputusan Pembelian Konsumen : Studi Kasus 212 Mart Cikaret. Jurnal Kajian Ekonomi \& Bisnis Islam, 2, 150-159.

Putra, G. P. (2017). Pengaruh Kualitas Produk Terhadap Keputusan Pembelian dan Dampaknya Terhadap Kepuasan Konsumen. Jurnal Administrasi Bisnis (JAB), 48 No. $1 J(6), 16$.

Reven, D., Ferdinand, T., \& Manajemen, J. (2017). Analisis Pengaruh Desain Produk, Kualitas Produk, Harga Kompetitif, Dan Citra Merek Terhadap Keputusan Pembelian (Studi Pada Pelanggan Nesty Collection Jakarta). Diponegoro Journal of Management, 6(3), 1-13.

Ruhamak, M. D., \& Syai'dah, E. H. (2018). The Influence of Word of Mouth, Consumer Interests and Brand Image on Consumer Decisions (Studies on Course Institution Students in the Pare English Village Area). Ekonika: University of Kadiri's Journal of Economics, 3(2), 14.

Sari, A., \& Widodasih, W. K. (2021). Pengaruh Gaya Hidup Terhadap Keputusan Pembelian Hijab Modiste.Id Di Sukatani Dimoderasi Oleh Variabel Religiusitas. Prodi Manajemen, Universitas Pelita Bangsa.

Setiyawan, D. (2019). Pengaruh Pendapatan, Gaya Hidup Konsumtif, dan Jenis Kelamin Terhadap Tingkat Konsumsi Mahasiswa Dengan Religiusitas Sebagai Variabel Moderating (Studi Kasus Mahasiswa FEBI IAIN Salatiga). IAIN Salatiga.

Shadiq, D. C. (2020). Pengaruh Bauran Pemasaran Terhadap Minat Beli Tamu Hotel Syariah Dengan Religiusitas Sebagai Variabel Moderasi. Sekolah Tinggi Ilmu Syariah Abu Zairi Bondowoso, Vol. 2 (1)32-59.

Sunyoto, D. (2013). Dasar-Dasar Manajemen Pemasaran. CAPS.

Tjiptono, F., Chandra, G., \& Adriana, D. (2008). Pemasaran Strategik. Andi. 